\title{
Survey for the Assessment of Groundnut Collar Rot Disease Incidence in Major Groundnut Growing Areas of Jodhpur, Rajasthan, India
}

\author{
Mahendra Kumar Saran ${ }^{1 *}$, Dama Ram ${ }^{1}$, J. R. Verma ${ }^{1}$, M. M. Kumawat ${ }^{2}$ and L. Netajit $^{3}$ \\ ${ }^{1}$ Department of Plant Pathology, ${ }^{2}$ Department of Entomology, ${ }^{3}$ Department of Agricultural \\ Statistics, CoA, Mandor, Agriculture University, Jodhpur, Rajasthan - 342304, India \\ *Corresponding author
}

A B S T R A C T

\section{Ke y w o r d s \\ Survey, Groundnut, Collar rot, Disease incidence \\ Article Info \\ Accepted: \\ 10 August 2020 \\ Available Online: \\ 10 September 2020}

A survey was conducted in major groundnut growing areas of different tehsil of Jodhpur district, Rajasthan during kharif 2019 to assess the distribution and the incidence of collar rot diseases. The highest incidences of collar rot were observed in Phalodi $(15.31 \%)$. Whereas, least collar rot incidence was observed $(10.0 \%)$ in Tewari. The overall average disease incidence of the Jodhpur district was (12.43\%) based on 125 fields surveyed in cropping season 2019.

\section{Introduction}

Groundnut (Arachis hypogaea L.) is an important and most widely grown food legume crop of both tropics and sub-tropics of the world, belonging the family leguminosae and sixth most important oilseed crop in the world. Groundnut kernals contain $48-50 \%$ of edible oil and 26-28\% protein, along with rich dietary fibre, minerals and vitamins (Ntare et al., 2008). China is the largest producer as well as consumer of groundnut in the world with $16.62 \mathrm{mt}$ followed by India $(6.7 \mathrm{mt})$, Nigeria (3.02 $\mathrm{mt}$ ) and United States $(2.57 \mathrm{mt}$ ) annually. India is first position in term of area and second in production. The Major groundnut growing states of India are Gujarat, Andhra Pradesh, Rajasthan, Tamil Nadu and Punjab.

The groundnut was cultivated in $4.8 \mathrm{~m}$ ha area with $6.7 \mathrm{mt}$ production having $1395 \mathrm{~kg} / \mathrm{ha}$ productivity. (Directorate of Economics and Statistics, Department of Agricultural, Cooperation and Welfare 2018-19).

In Rajasthan the area, production and productivity of groundnut was $0.73 \mathrm{~m}$ ha, $1.56 \mathrm{mt}$ and $2131 \mathrm{~kg} / \mathrm{ha}$, respectively. The major groundnut growing districts in Rajasthan are Bikaner, Jaipur, Sikar, Churu, Dausa, Udaipur and Nagaur. 
(Commissionerate of Agriculture, Rajasthan Jaipur, 2019). The crop suffers from more than 50 pathogens including fungi, bacteria, viruses and nematodes (Grover, 1981) However, only a few are economically important in India, such as early and late leaf spot (Cercospora arachidicola \& $C$. personata), collar rot (Aspergillus niger van Teigham), rust (Puccinia arichidis), stem rot (Sclerotium rolfsii Sacc.), afla root (Aspergillus flavus), root rot (Macrophomina phaseolina) diseases.

Nematode diseases like root knot and viral diseases like peanut bud necrosis, peanut stem necrosis, groundnut mottle and clump (Ghewande et al., 1986).

Aspergillus niger van Tieghem causing collar rot disease on groundnut seedlings was first reported by Jochem (1926) and in India it was reported by Jain and Nema (1952) as Aspergillus blight.

The annual yield losses due to collar rot alone are approximately $5 \%$, the disease has a potential to damage the crop with $40 \%$ losses (Bakhetia, 1983). Losses due to preemergence phase of the disease are up to $15 \%$, whereas post-emergence phase accounts to $2 \%$ losses (Rasheed et al., 2004).

In India, the losses may account to 40 to $50 \%$ in terms of seedling mortality due to A. niger (Ghewande et al., 2002). Many seed dressing fungicides are effective against collar rot of groundnut (Gangopadhayay and Bhatia, 1996; Karthikeyan, 1996). Trichoderma spp. also used as biological control agent against most of soil-borne plant pathogenic fungi (Kucuk and Kivank, 2003).

\section{Materials and Methods}

Weekly survey of ground nut collar rot was carried out at five Tahsil viz. Balesar, Tewari,
Lohawat, Phalodi and Osian of Jodhpur district to study the incidence of collar rots, from second week of July to fourth week of October during Kharif 2019 (Table 1). At each Tahsil five villages situated in different geographical directions and five fields per village were selected.

The each village/field selected for disease incidence, an area of $1 \times 1 \mathrm{~m}^{2}$ was marked diagonally across the field at five spots on each farmer's field and percent disease incidence (PDI) was calculated by counting the diseased and the total number plant per spot.

The plant showing collar rot symptoms was considered as a diseased plant. During survey, personal discussions were also held with the cultivators regarding occurrence and severity of the disease, agronomic practices and field history.

The per cent disease incidence was calculated by using the following formula:

$$
\text { Percent disease incidence }=\frac{\text { Number of infected plant }}{\text { Total number of plant }} \times 100
$$

\section{Results and Discussion}

The average collar rot incidence in different Tahsil of Jodhpur district varied from (10.0 to $15.31 \%)$. In Phalodi disease incidence was maximum (15.31\%) followed by Osian (13.43\%), Lohawat (12.90\%) followed by Balesar (10.55\%) and least collar rot incidence was observed (10.0\%) in Tewari.

However, the disease incidence was recorded (10.0 to $15.31 \%$ ) in Tahsil of Jodhpur district, respectively (Table 1 and Fig. 1-3). The overall average disease incidence of the Jodhpur district was $(12.43 \%)$ based on 125 fields surveyed in cropping season 2019. 
Table.1 Incidence of groundnut collar rot disease, Jodhpur, Rajasthan in Kharif 2019

\begin{tabular}{|c|c|c|c|c|c|c|}
\hline $\begin{array}{c}\text { Sample } \\
\text { No. }\end{array}$ & $\begin{array}{c}\text { Isolate } \\
\text { No. }\end{array}$ & Districts & Tahsil & Village & $\begin{array}{l}\text { \% Disease } \\
\text { Incidence }\end{array}$ & Average \\
\hline \multirow[t]{5}{*}{1.} & \multirow[t]{5}{*}{ JU-01 } & \multirow[t]{5}{*}{ Jodhpur } & \multirow[t]{5}{*}{ Balesar } & Sukhmadla & 12.71 & \multirow[t]{5}{*}{10.55} \\
\hline & & & & Lorta & 11.45 & \\
\hline & & & & Belwa & 11.45 & \\
\hline & & & & Dewasu & 10.57 & \\
\hline & & & & Bastawa & 6.59 & \\
\hline \multirow[t]{5}{*}{2.} & \multirow[t]{5}{*}{ JU-02 } & \multirow[t]{5}{*}{ Jodhpur } & \multirow[t]{5}{*}{ Tewari } & Mathania & 6.42 & \multirow[t]{5}{*}{10.0} \\
\hline & & & & Gewada & 10.78 & \\
\hline & & & & Indroka & 8.51 & \\
\hline & & & & Narwa & 12.69 & \\
\hline & & & & Manaklav & 11.57 & \\
\hline \multirow[t]{5}{*}{3.} & \multirow[t]{5}{*}{ JU-03 } & \multirow[t]{5}{*}{ Jodhpur } & \multirow[t]{5}{*}{ Lohawat } & Pilawa & 16.92 & \multirow[t]{5}{*}{12.90} \\
\hline & & & & Sadri & 13.91 & \\
\hline & & & & Dechu & 10.84 & \\
\hline & & & & Kushlawa & 5.93 & \\
\hline & & & & Sagra & 16.92 & \\
\hline \multirow[t]{5}{*}{4.} & \multirow[t]{5}{*}{ JU-04 } & \multirow[t]{5}{*}{ Jodhpur } & \multirow[t]{5}{*}{ Phalodi } & Mukeri & 21.92 & \multirow[t]{5}{*}{15.31} \\
\hline & & & & Mandala kala & 16.15 & \\
\hline & & & & Sawrij & 15.96 & \\
\hline & & & & Aeka Sageri & 11.86 & \\
\hline & & & & Bengti & 10.67 & \\
\hline \multirow[t]{5}{*}{5.} & \multirow[t]{5}{*}{ JU-05 } & \multirow[t]{5}{*}{ Jodhpur } & \multirow[t]{5}{*}{ Osian } & Bhikamkhor & 9.87 & \multirow[t]{5}{*}{13.43} \\
\hline & & & & Hanuman Sagar & 10.87 & \\
\hline & & & & Harlaya & 18.43 & \\
\hline & & & & Padasala & 13.34 & \\
\hline & & & & Bhad & 14.65 & \\
\hline
\end{tabular}

Fig.1 View of groundnut collar rot infected field

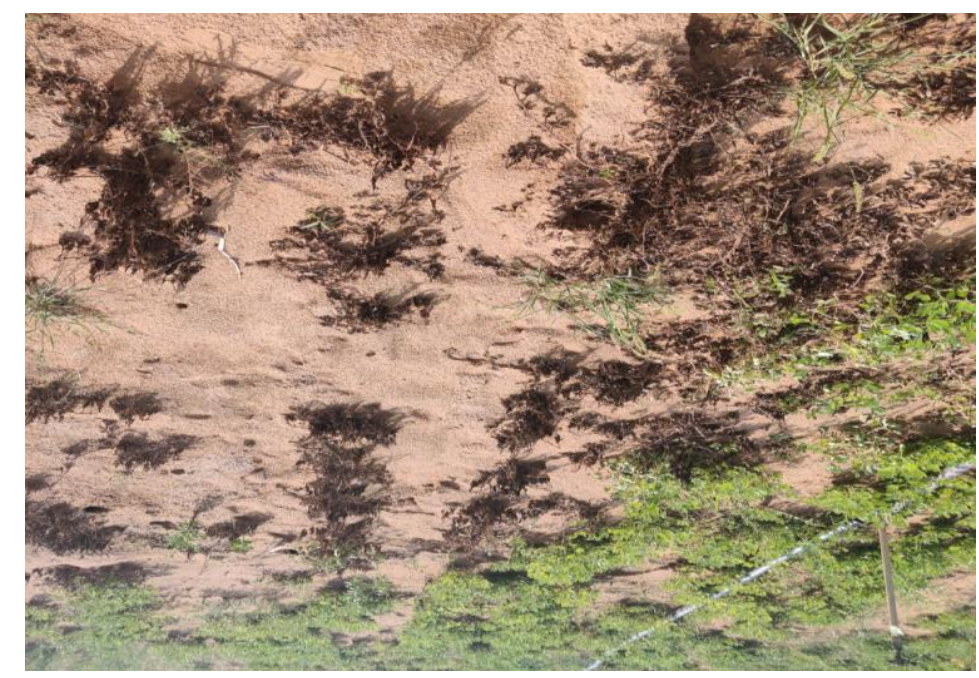


Fig.2 View during the survey program

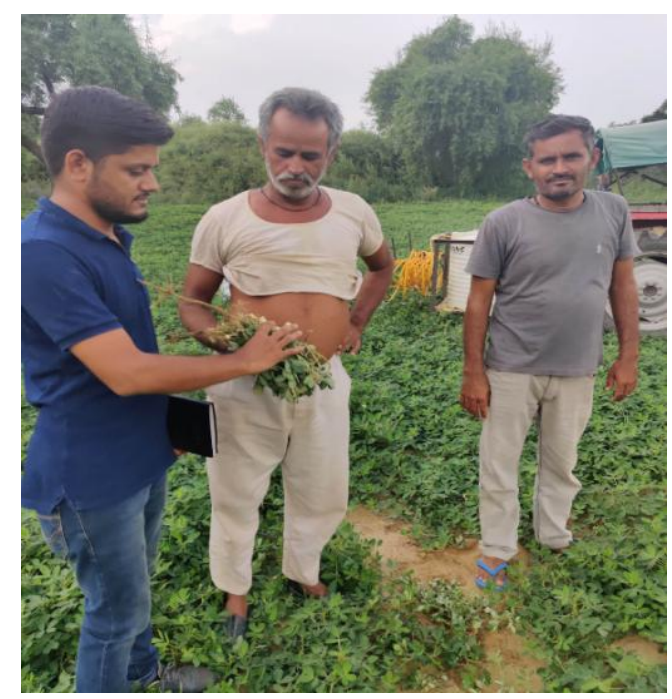

Fig.3 Incidence of groundnut collar rot disease, Jodhpur, Rajasthan

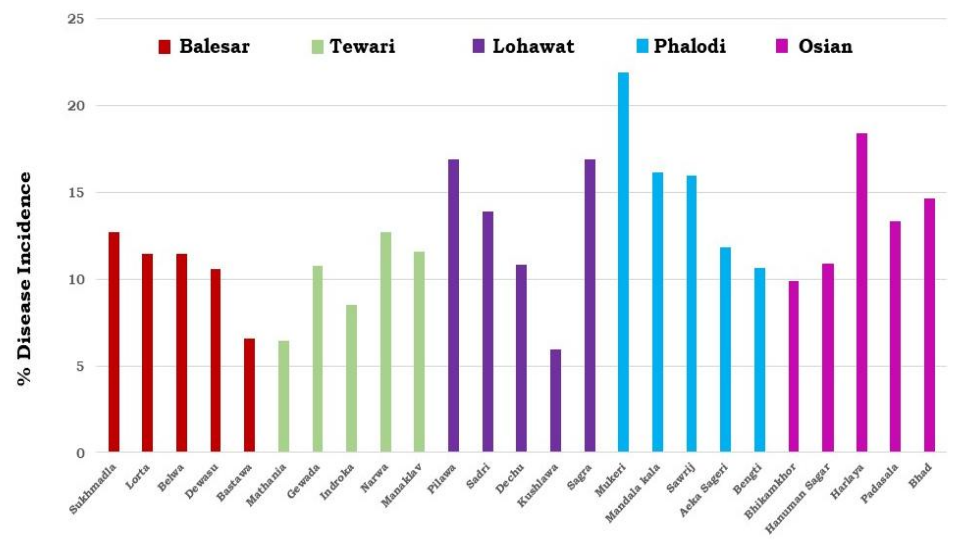

In conclusion the field surveys were made on the status of collar rot in the major groundnut growing areas of Jodhpur district of Rajasthan the average collar rot incidence in different tehsil of district varied from10.0 to 15.31 per cent.

\section{References}

Anonymous, 2019. Commissionerate of Agriculture, Rajasthan -Jaipur.

Anonymous, 2018-19. Directorate of Economics and Statistics, Department of Agricultural, Cooperation and
Welfare.

Bakhetia, D. R. C. 1983. Control of white grub (Holotrichia consenguinea) and collar rot (Aspergillus niger) of groundnut sown in different dates in Punjab. Indian J. Agric. Sci. 53(9): 846850.

Gangopadhyay, S. and Bhatia, J. N., 1996. Sources of resistance to collar rot and leaf spots of groundnut in Rajasthan. Indian J. Mycol. Pl. pathol. 26(1): 108109.

Ghewande, M. P., Desai, S. and Basu, M. S., 2002. Diagnosis and management of 
major diseases of groundnut. $N R C G$ Bull. pp. 8-12.

Ghewande M.P., Reddy P.S. 1986. Strategy for the management of major diseases of groundnut. Pesticides 20: 57-61.

Grover R.K., 1981. Present state of research and future trends in controlling diseases of oilseeds and pulses. In: PAI National Seminar on Increasing of Pulses and Oilseeds Production Through Plant Protection. Vigyan Bhavan, New Delhi, 13-14 November, 1981, 315 pp.

Jain, A. C. and Nema, K. G., 1952. Aspergillus blight of groundnut seedlings. Sci. Cult. 17: 348-349.

Jochem, S. C. J., 1926. Aspergillus niger on groundnut. Indisch Culturen (Teysmannia). 11: 325-326.

Karthikeyan, A., 1996. Effect of organic amendments antagonist Trichoderma viride and fungicides on seed and collar rot of groundnut. Pl. Dis. Res. 11(1): 72-74.

Kucuk, C. and Kivank, M., 2003. Isolation of Trichoderma spp. and determination of their antifungal, biochemical and physiological features. Turkey J. Bio., 27: 247-253.

Ntare, B.R., Diallo, A.T., Ndjeunga, J and Waliyar, F. 2008. Groundnut Seed Production Manual. Patancheru, 502324. Andhra Pradesh, India. International Crops Research International for the Semi-Arid Tropics (ICRISAT). 20.

Rasheed, S., Dawarand, S and Ghaffar, A. 2004. Location of fungi in groundnut seed. Pakistan Journal of Botany. 36(3): 663-668.

\section{How to cite this article:}

Mahendra Kumar Saran, Dama Ram, J. R. Verma, M. M. Kumawat and Netajit, L. 2020. Survey for the Assessment of Groundnut Collar Rot Disease Incidence in Major Groundnut Growing Areas of Jodhpur, Rajasthan, India. Int.J.Curr.Microbiol.App.Sci. 9(09): 1162-1166. doi: https://doi.org/10.20546/ijcmas.2020.909.144 